\title{
Lietuvos gyventojų susidūrimo su korupcija ir pasitenkinimo gyvenimu paradoksas
}

\author{
Aistė Diržytė, Aleksandras Patapas \\ Mykolo Romerio universitetas \\ Ateities g. 20, LT-08303 Vilnius, Lietuva \\ DOI:10.13165/VPA-15-14-2-01
}

\begin{abstract}
Anotacija. Nors korupcijos fenomenas ivvairiose valstybèse buvo tyrinètas ịvairiais skerspjūviais, taikant ivvairius teorinius modelius, Lietuvoje atliktas reprezentatyvios imties ( $n=1002)$ tyrimas, su kuriuo supažindinama šiame straipsnyje, papilde moksliniu tyrimu apie korupcijos reiškini bazę. Daugiau asmenu, dirbančiu privačiame sektoriuje, lyginant su dirbančiais viešajame sektoriuje, teigè susiduriantys su korupcija gyvenamosios vietovès ịstaigose, savivaldybès ir valstybinèse ịstaigose, švietimo, medicinos ir teisésaugos institucijose, taip pat verslo sektoriuje. Tyrimo rezultatai atskleidè, jog Lietuvoje yra žymiai daugiau susiduriančiu su korupcija nei nesusiduriančiu su korupcija asmenu, o kai kuriuose segmentuose, pavyzdžiui, gyvenamosios vietovés istaigose, susidūrimo su korupcija rodikliai yra ypatingai aukšti. Šiame straipsnyje pateikto tyrimo rezultatai supažindina su Lietuvos gyventojų imties susidūrimo su korupcija ir pasitenkinimo gyvenimu paradoksu. Buvo keliama hipoteze, kad asmenys, kurie nesusiduria su korupcija, yra labiau patenkinti gyvenimu Lietuvoje, taip pat labiau patenkinti ịvairiomis savo gyvenimo sritimis. Gauti duomenys yra paradoksalūs - jie ne tik nepatvirtino keltos hipotezès, bet pademonstravo visiškai priešinga, nei buvo tikétasi, efektą: dažniau susiduriantys su korupcija asmenys buvo statistiškai reikšmingai labiau patenkinti galimybe dirbti, atlyginimu, galimybe derinti darba ir poilsi, finansine situacija, vartojimo galimybemis, gyvenimo salygomis, gyvenamaja aplinka, kultüriniu gyvenimu, profesiniu gyvenimu, dvasiniu gyvenimu, psichologine gerove, savo materialine padetimi, medicinos paslaugu prieinamumu, gyvenimu Lietuvoje apskritai. Paradoksas turètų büti toliau tyrinejamas.
\end{abstract}

Raktažodžiai: korupcija, emocijos, pasitenkinimas gyvenimu.

Keywords: corruption, emotions, satisfaction with life. 


\section{Ivadas}

Korupcijos sąvoka kilusi iš lotynų kalbos žodžio „corrumpo“, kuris reiškia „pagadinti, sunaikinti, paversti niekais“ arba „,iškreipti, išvesti iš kelio, papirkti“. Sąvokos reikšmès atspindi korupcijos poveikio visuomenei ir jos moralinėms vertybėms esmę: korupcija naikina tai, ką nuo civilizacijos pradžios pati visuomené mėgino sukurti normomis, taisyklèmis, standartais - pačią visuomenès tvarką, takoskyrą tarp „leistina“ ir „neleistina“, visuomenès tikejjimą „taisykles atitinkančio“ ir „taisyklių neatitinkančio“ elgesio pasekmių prognozavimu, nulemiantị atskiru individų prosocialią moralinę savireguliaciją. Korupcijos fenomenas paskatina netikejjimą pačiomis visuomeninès santvarkos taisyklëmis, abejojimą jų pagrịstumu, nepasitikejjimą tvarką visuomenejje kuriančiomis arba saugojančiomis institucijomis [12].

Korupcija reiškia, F. Nietzsche žodžiais tariant, Dievo mirtị valstybejje, kai nebèra „gyvo tikèjimo“ pačia visuomeninès savireguliacijos sistema, kai „dvigubi standartai“" reiškia moralinę tuštumą anapus jų, kai formalios taisyklès ar jų pažeidimo pasekmès baugina tik tuos, kurie neturi pakankamai lèšu ,,išpirkai“ už taisyklių nesilaikymą sumokèti. Lygiai kaip ,,indulgencijų“ laikais buvo galima gauti „nuodèmių išpirkimąa, bet pats faktas labai pakenkẻ tiek Bažnyčios, tiek tų, kuriems ji teige atstovaujanti, autoritetui, taip ir dabartineje visuomeneje korupcijos fenomenas daro didelę žalą valstybès autoritetui, sumenkindamas žmonių tikèjimą valstybès funkcionavimo moraliniais pagrindais [15].

Korupcijos fenomenas tyrinètas ịvairių mokslų (politikos, ekonomikos, vadybos, teisès, sociologijos, psichologijos), taip pat ir tarpdisciplininių sričių kontekstuose. Jam aiškinti buvo pasitelktos įvairios teorijos - hierarchinio kompleksiškumo modelis (Commons, 2008; Fein \& Weibler, 2014), situacinių aplinkybių teorija (Rabl 2011), institucinio poveikio teorija (Maravic, 2007), bendros darbinès atmosferos teorija (Chang \& Lai, 2002), priežastinių ryšiu ir veiksnių sąveikų teorija (Aguilera \& Vadera, 2008; Lange, 2009; Beugré, 2010; Shadnam \& Lawrence, 2011) ir net klasikinè moralinių sprendimų ir moralinès raidos teorija (Kohlberg, 1984). Nepaisant mokslininkų pastangų tiriant korupcijos fenomeną [16; 17], naujų testavimo įrankių kūrimo [13] ir augančio susidomėjimo korupcijos fenomenu [14], korupcijos mastai daugelyje valstybių, ịskaitant Lietuvą, nuolat dideja. Tai reiškia, kad reikia daugiau demesio skirti išsamiems tarpdisciplininiams korupcijos reiškinio tyrimams.

Lietuvoje korupcijos fenomenas psichologiniu aspektu dar nèra išsamiai tyrinètas, todèl tyrimas, su kuriuo supažindinama šiame straipsnyje, yra unikalus - jis atskleidžia reprezentatyvios gyventojų imties požiūrio ị korupciją ypatumus, taip pat korupciją skirtingai vertinančių grupių psichologinius profilius. 


\section{Metodologija}

\section{Tyrimo imtis ir procedūra}

Lietuvos gyventojų tyrimas buvo atliktas daugiapakopès tikimybinės atrankos būdu. Kitaip tariant, respondentų atranka parengta taip, kad kiekvienas Lietuvos gyventojas turètų vienodą tikimybę būti apklaustas. Visi tiriamieji buvo asmeniškai prašomi dalyvauti tyrime, apklausos būdas: interviu respondento namuose. Tyrimas buvo atliekamas 2014 m. Vilniuje, Kaune, Klaipèdoje, Šiauliuose, Panevėžyje, Druskininkuose, Kretingoje, Alytaus, Šakių, Pakruojo, Utenos, Tauragès, Švenčionių, Raseinių, Kupiškio, Akmenès, Rokiškio, Lazdijų, Telšių, Mažeikių, Marijampolès, Anykščių, Varénos, Molètų ir Ukmergès rajonuose. Tyrimas vyko 20 miestų ir 29 kaimuose.

Bendras respondentų skaičius - 1002 asmenys, 469 vyrai (46,8 proc.) ir 533 (53,2 proc.) moterys. Tiriamųjų amžiaus vidurkis - 49,29 metai (tiriamųjų amžius nuo 18 iki 90 metų, standartinis nuokrypis - 16,206). Didžioji dalis tiriamųjų buvo susituokę ( 48,9 proc.), kai kurie - gyveno su partneriu (9,7 proc.), dalis buvo išsiskyrusiu (12,2 proc.), dalis - našlių (13,8 proc.) arba gyveno vieni (12 proc.). Didžioji dalis tiriamųjų turejjo aukštesnịji išsilavinimą (51,4 proc.), tačiau kai kurie turèjo tik pradini (2,7 proc.) arba vidurinị (6,5 proc.) išsilavinimą. Apklaustų Lietuvos gyventojų pajamos šeimai per mėnesị (neskaičiuojant mokesčių) buvo tokios: didžiosios dalies tiriamųjų (44,7 proc.) pajamos siekẻ mažiau kaip 1500 Lt, kai kurių (37,4 proc.) - nuo $1501 \mathrm{Lt}$ iki $3000 \mathrm{Lt}$, mažos dalies (13,3 proc.) pajamos buvo 3001$6000 \mathrm{Lt}$ ir tik 2,2 proc. pajamos siekè daugiau kaip $6001 \mathrm{Lt}$, o 0,1 proc. - daugiau kaip $20000 \mathrm{Lt}$.

Tyrimą Mykolo Romerio universiteto užsakymu pagal projektą Nr. VP1-3.1ŠMM-07-K-03-032 atliko Visuomenès nuomonès ir rinkos tyrimu centras „Vilmorus“. Šiame straipsnyje supažindinama tik su kai kuriais tyrimo duomenimis, nors pats tyrimas apėmė platų spektrą sričių. I klausimus apie korupcijos patirtị atsakè tik 53 proc. tyrime dalyvavusių respondentų.

\section{Tyrimo metodai}

Šiuo tyrimu siekėme patikrinti, ar Lietuvos gyventojai, kurie teigia susiduriantys su korupcija, nėra nuolat patiriantys neigiamas emocines būsenas arba apskritai labai nepatenkinti savo gyvenimu. Moksliniai tyrimai rodo, kad jeigu asmeniui būdingas neigiamas emocingumas, jeigu jis jaučiasi nelaimingas, nepatenkintas savo gyvenimu, tai gali paveikti ir kitu sričių vertinimą - jam viskas atrodys „blogai“, jis ịžvelgs „sąmokslą“, „piktus kèslus“ ten, kur jų gali ir nebūti. Taigi, Lietuvos gyventojų tyrimo klausimynui sudaryti buvo panaudoti atitinkami ịvertinimo instrumentai: 
1) Lietuvos gyventojų susidūrimui su korupcija ịvertinti buvo naudojama tyrimo autorių sukurta Korupcijos patirties skalè. Šią skalę sudaro septyni klausimai:

1. Ar esate susidūręs su korupcija, nesąžiningumu teisésaugos institucijose?

2. Ar esate susidūręs su korupcija, nesąžiningumu verslo sektoriuje?

3. Ar esate susidūręs su korupcija, nesąžiningumu medicinos institucijose?

4. Ar esate susidūręs su korupcija, nesąžiningumu švietimo institucijose?

5. Ar esate susidūręs su korupcija, nesąžiningumu valstybinèse ịstaigose?

6. Ar esate susidūręs su korupcija, nesąžiningumu savivaldybès ịstaigose?

7. Ar esate susidūręs su korupcija, nesąžiningumu Jūsu gyvenamos vietovès istaigose?

Skalès patikimumas buvo pakankamas: Cronbacho alfa tiriamųjų imčiai Lietuvos populiacijoje buvo $\alpha=.818$.

2) Lietuvos gyventojų emocinėms būsenoms ịvertinti buvo sukurta speciali Emocinio patyrimo skalè, kuri yra tyrimo autoriu modifikuota 1994 metais Watsono sukurtos skalès (angl. Positive and Negative Affect Scale, PANAS) versija. Tiriamieji turi ịvertinti, kiek stipriai jautė kiekvieną iš būsenų per paskutinę savaitę. Teiginiai vertinami 6 balų Likerto atsakymų skalèje nuo 1- „Nejaučiau“ iki 6 - „Jaučiau labai dažnai ir stipriai“. Šiame straipsnyje supažindiname su neigiamų būsenų poskale, kurią sudare 13 klausimų:

1. Kiek stipriai per paskutinę savaitę jautète: nuoskaudą?

2. Kiek stipriai per paskutinę savaitę jautėe: pykti?

3. Kiek stipriai per paskutinę savaitę jautète: nerima?

4. Kiek stipriai per paskutinę savaitę jautete: psichologini skausmą?

5. Kiek stipriai per paskutinę savaitę jautete: kaltę?

6. Kiek stipriai per paskutinę savaitę jautète: liūdesį?

7. Kiek stipriai per paskutinę savaitę jautète: baimę?

8. Kiek stipriai per paskutinę savaitę jautėte: nenora gyventi?

9. Kiek stipriai per paskutinę savaitę jautète: neviltį?

10. Kiek stipriai per paskutinę savaitę jautète: bejejgiškuma?

11. Kiek stipriai per paskutinę savaitę jautète: beprasmiškumą?

12. Kiek stipriai per paskutinę savaitę jautète: gèda?

13. Kiek stipriai per paskutinę savaitę jautete: stresą?

Skalès patikimumas buvo pakankamas: Cronbacho alfa tiriamųjų imčiai Lietuvos populiacijoje buvo $\alpha=.869$.

3) Lietuvos gyventojų tyrime taip pat buvo naudojama tyrimo autorių sukurta Pasitenkinimo ịvairiomis gyvenimo sritimis skalè. Šiame straipsnyje supažindiname tik su kai kuriais tyrimo duomenimis, gautais naudojant 14 klausimų poskalę. 5 balų Likerto skalëje buvo vertinamas pasitenkinimas įvairiomis gyvenimo sritimis: nuo 1- „Visiškai nepatenkintas“ iki 5 - „Visiškai patenkintas“.

1. Kiek esate patenkintas galimybe dirbti?

2. Kiek esate patenkintas atlyginimu?

3. Kiek esate patenkintas galimybe derinti darba ir poilsi? 
4. Kiek esate patenkintas finansine situacija?

5. Kiek esate patenkintas vartojimo galimybemis?

6. Kiek esate patenkintas gyvenimo sąlygomis?

7. Kiek esate patenkintas gyvenamaja aplinka?

8. Kiek esate patenkintas materialine padetimi?

9. Kiek esate patenkintas kultūriniu gyvenimu?

10. Kiek esate patenkintas profesiniu gyvenimu?

11. Kiek esate patenkintas dvasiniu gyvenimu?

12. Kiek esate patenkintas psichologine gerove?

13. Kiek esate patenkintas medicinos paslangu prieinamumu?

14. Kiek esate patenkintas gyvenimu Lietuvoje apskritai?

Skalès patikimumas buvo pakankamas: Cronbacho alfa tiriamųjų imčiai Lietuvos populiacijoje buvo $\alpha=.65$

\section{Rezultatai}

Atliekant tyrimą, pirmiausia buvo siekiama nustatyti, kiek asmenų prisipažins susidūrę su korupcija, taip pat išsiaiškinti, kuriame sektoriuje dirbantys asmenys viešajame ar privačiame - teigs dažniau susiduriantys su korupcija.

Kaip matome 1 lentelèje, daugiau asmenų, dirbančių privačiame sektoriuje, lyginant su dirbančiais viešajame sektoriuje, teigè susiduriantys su korupcija gyvenamosios vietovès įstaigose, savivaldybès ir valstybinèse įstaigose, švietimo, medicinos ir teisėsaugos institucijose, taip pat verslo sektoriuje. Be to, žymiai daugiau buvo apskritai susiduriančių su korupcija nei nesusiduriančių su korupcija asmenų, o kai kuriuose segmentuose, pavyzdžiui, gyvenamos vietovès ịstaigose, susidūrimo su korupcija rodikliai buvo ypatingai aukšti.

\section{1 lentelè. Susidūrimo su korupcija dažnių pasiskirstymas}

\begin{tabular}{|c|c|c|c|c|c|c|}
\hline & \multirow{2}{*}{ Viešasis } & \multicolumn{4}{|c|}{$\begin{array}{c}\text { Sektorius, kuriame respondentas } \\
\text { dirba }\end{array}$} & \multirow{3}{*}{$\begin{array}{c}\text { Iš viso } \\
125\end{array}$} \\
\hline & & \multirow{2}{*}{\begin{tabular}{|c} 
Privatus \\
50
\end{tabular}} & \multirow{2}{*}{\begin{tabular}{|c|}
$\begin{array}{c}\text { Abu } \\
\text { sektoriai }\end{array}$ \\
69
\end{tabular}} & \multirow{2}{*}{$\begin{array}{c}\begin{array}{c}\text { Neat- } \\
\text { sakè }\end{array} \\
5\end{array}$} & \multirow[b]{2}{*}{1} & \\
\hline Gyvenamos & Nesusiduria su korupcija & & & & & \\
\hline vietovés įstaigose & Susiduria su korupcija & 165 & 227 & 14 & 3 & 409 \\
\hline Savivaldybès & Nesusiduria su korupcija & 62 & 97 & 5 & 1 & 165 \\
\hline istaigose & Susiduria su korupcija & 153 & 199 & 15 & 3 & 370 \\
\hline Valstybinése & Nesusiduria su korupcija & 92 & 119 & 7 & 1 & 219 \\
\hline istaigose & Susiduria su korupcija & 123 & 176 & 13 & 3 & 315 \\
\hline Švietimo & Nesusiduria su korupcija & 48 & 72 & 8 & 2 & 130 \\
\hline institucijose & Susiduria su korupcija & 167 & 224 & 12 & 2 & 405 \\
\hline Medicinos & Nesusiduria su korupcija & 119 & 166 & 14 & 1 & 300 \\
\hline institucijose & Susiduria su korupcija & 95 & 130 & 6 & 3 & 234 \\
\hline
\end{tabular}




\begin{tabular}{|l|l|c|c|c|c|c|}
\hline \multirow{2}{*}{ Verslo sektoriuje } & Nesusiduria su korupcija & 62 & 123 & 9 & 1 & 195 \\
\cline { 2 - 7 } & Susiduria su korupcija & 153 & 173 & 11 & 3 & 340 \\
\hline \multirow{2}{*}{$\begin{array}{l}\text { Teisésaugos } \\
\text { institucijose }\end{array}$} & Nesusiduria su korupcija & 68 & 118 & 11 & 2 & 199 \\
\cline { 2 - 7 } & Susiduria su korupcija & 147 & 178 & 9 & 2 & 336 \\
\hline
\end{tabular}

Atlikus koreliacinę susidūrimo su korupcija ịvairiuose sektoriuose analizę, kaip matome 2 lentelèje (pastaba: ** - koreliacija reikšminga 0,01 lygmeniu), paaiškejo, kad aukščiausia susidūrimo su korupcija koreliacija stebima tarp valstybės ir savivaldybės įstaigu $(\mathrm{r}=.620, \mathrm{p}<0,01)$ bei savivaldybių ịstaigų ir ịstaigų gyvenamosios vietos aplinkoje $(\mathrm{r}=.565, \mathrm{p}<0,01)$.

\section{2 lentelè. Susidūrimo su korupcija įvairiuose sektoriuose sąsajos, Pearsono koreliacinè analizė}

\begin{tabular}{|l|c|c|c|c|c|c|}
\hline & $\begin{array}{c}\text { Teisėsau- } \\
\text { gos }\end{array}$ & Verslo & $\begin{array}{c}\text { Medi- } \\
\text { cinos }\end{array}$ & Švietimo & Valstybės & $\begin{array}{c}\text { Savival- } \\
\text { dybių }\end{array}$ \\
\hline Teisėsaugos & 1,000 & & & & & \\
\hline Verslo &, $426^{* *}$ & 1,000 & & & & \\
\hline Medicinos &, $325^{* *}$ &, $341^{* *}$ & 1,000 & & & \\
\hline Švietimo &, $310^{* *}$ &, $363^{* *}$ &, $296^{* *}$ & 1,000 & & \\
\hline Valstybes &, $434^{* *}$ &, $429^{* *}$ &, $366^{* *}$ &, $437^{* *}$ & 1,000 & \\
\hline Savivaldybių &, $407^{* *}$ &, $428^{* *}$ &, $300^{* *}$ &, $371^{* *}$ &, $\mathbf{6 2 0} * *$ & 1,000 \\
\hline $\begin{array}{l}\text { Istaigose gyvenamosios } \\
\text { vietos aplinkoje }\end{array}$ &, $340^{* *}$ &, $347^{* *}$ &, $292^{* *}$ &, $336^{* *}$ &, $468^{* *}$ &, $\mathbf{5 6 5 * *}$ \\
\hline
\end{tabular}

Taip pat siekème analizuoti susidūrimą su korupcija pagal pajamų grupes. Šiam tikslui pirmiausia atlikome klasterinę respondentų pajamų analizę pagal $\mathrm{K}$ vidurkius, ir tokiu būdu buvo išskirti 3 pajamų klasteriai - $1368 \mathrm{Lt}, 3725 \mathrm{Lt}$ ir 10127 Lt. Kaip matome 3 lentelèje, ANOVA analizė atskleidè statistiškai reikšmingus susidūrimo su korupcija dažnių pasiskirstymo skirtumus pajamų grupèse. Tiesa, šie skirtumai išryškejjo tik teisèsaugos $\mathrm{F}(2,904)=7,701, \mathrm{p}=, 000$, verslo $\mathrm{F}(2,905)=12,392, \mathrm{p}=, 000$, valstybès įstaigų sektoriuose $\mathrm{F}(2,902)=3,474$, $\mathrm{p}=, 031$ bei vertinant korupciją visuose sektoriuose apskritai $\mathrm{F}(2,900)=5,367$, $\mathrm{p}=, 005$.

3 lentelè. Susidūrimas su korupcija pagal pajamų grupes, ANOVA analizè

\begin{tabular}{|l|c|c|c|}
\hline & $\mathrm{df}$ & $\mathrm{F}$ & $\mathrm{p}$ \\
\hline \multirow{2}{*}{ Teisėsaugos sektoriuje } & 2 & 7,701 & $\mathbf{, 0 0 0}$ \\
\cline { 2 - 4 } & 904 & & \\
\hline \multirow{2}{*}{ Verslo sektoriuje } & 2 & 12,392 & $\mathbf{, 0 0 0}$ \\
\cline { 2 - 4 } & 905 & & \\
\hline
\end{tabular}




\begin{tabular}{|l|c|c|c|}
\hline \multirow{2}{*}{ Valstybės sektoriuje } & 2 & 3,474 & $\mathbf{0 3 1}$ \\
\cline { 2 - 4 } & 902 & & \\
\hline $\begin{array}{l}\text { Visuose sektoriuose kartu } \\
\text { (korupcija apskritai) }\end{array}$ & 2 & 5,367 & $\mathbf{, 0 0 5}$ \\
\cline { 2 - 4 } & 900 & & \\
\hline
\end{tabular}

Tuckey HSD testas atskleidè, kaip matome 4 lentelèje, jog mažiausių pajamų asmenys teigè dažniausiai susiduriantys su korupcija teisėsaugos, verslo, valstybės ìstaigų sektoriuose bei vertinant korupciją visuose sektoriuose apskritai, lyginant su kitomis pajamų grupėmis.

\section{4 lentelè. Susidūrimo su korupcija pagal pajamų grupes skirtumai, Post-Hoc Tukey HSD testas}

\begin{tabular}{|c|c|c|c|c|c|c|}
\hline & $\begin{array}{l}\text { (I) Pajamų } \\
\text { grupé }\end{array}$ & (J) Pajamų & $\begin{array}{c}\text { Vidurkių } \\
\text { skirtumas }\end{array}$ & $\mathbf{p}$ & & \\
\hline \multirow{2}{*}{$\begin{array}{l}\text { Teisésaugos } \\
\text { sektoriuje }\end{array}$} & \multirow{2}{*}{$1368 \mathrm{Lt}$} & $3725 \mathrm{Lt}$ &, $09855^{*}$ &, 026 & ,0096 & ,1875 \\
\hline & & $10127 \mathrm{Lt}$ & ,33746* & ,005 &, 0841 & ,5908 \\
\hline \multirow{2}{*}{ Verslo sektoriuje } & \multirow{2}{*}{$1368 \mathrm{Lt}$} & $3725 \mathrm{Lt}$ & ,17824* &, 000 &, 0921 & ,2644 \\
\hline & & $10127 \mathrm{Lt}$ & ,14892 &, 310 &,- 0903 & ,3881 \\
\hline \multirow{2}{*}{ Valstybès sektoriuje } & \multirow{2}{*}{$1368 \mathrm{Lt}$} & $3725 \mathrm{Lt}$ & ,02120 &, 850 &,- 0704 &, 1128 \\
\hline & & $10127 \mathrm{Lt}$ & ,28962* & ,025 & ,0294 &, 5498 \\
\hline \multirow{2}{*}{ Korupcija apskritai } & \multirow{2}{*}{$1368 \mathrm{Lt}$} & $3725 \mathrm{Lt}$ & ,06312* & ,036 &, 0032 &, 1231 \\
\hline & & $10127 \mathrm{Lt}$ & ,16834 & ,052 &,- 0013 & ,3379 \\
\hline
\end{tabular}

*- vidurkių skirtumas yra reikšmingas 0.05 lygmeniu.

Kaip minèta, šiame tyrime kèlème prielaidą, kad galbūt ne visuomet galima pasitikèti tiriamųjų atsakymais, ypač jeigu jiems būdingas neigiamas emocingumas. Kai kurie autoriai, pavyzdžiui, Sonya Lyubomirkyj, yra ne kartą ịvairiais tyrimais pademonstravę, jog kai asmuo yra nelaimingas, apimtas neigiamų emocijų, tuomet jam „pasaulis“, „valstybe““, ,aplinka“ gali atrodyti „,blogi“, „piktavaliai“, „supuvę“. Laikantis šios pozicijos, galima teigti, kad nelaimingi, neigiamų emocijų apimti asmenys linkę labiau pastebèti ịvairius net ir menkus jų teisių arba moralinių normų pažeidimus, jie jautresni ir žymiai labiau neigiamai vertina tai, kas vyksta jų aplinkoje. Siekdami palyginti emocinį patyrimą respondentų, kurie teige „dažnai susiduriantys" ir „beveik nesusiduriantys“ su korupcija, atlikome Mann-Whitney analizę. 


\section{5 lentelè. Susidūrimo su korupcija ir neigiamų emocijų patyrimo palyginimas, Mann-Whitney testas}

\begin{tabular}{|c|c|c|c|c|c|c|}
\hline Emocijos & & $\begin{array}{c}\text { Vidutiniai } \\
\text { rangai }\end{array}$ & $\begin{array}{l}\text { Rangų } \\
\text { suma }\end{array}$ & $\mathbf{N}$ & $\begin{array}{c}\text { Mann- } \\
\text { Whitney }\end{array}$ & p \\
\hline \multirow{3}{*}{ Beprasmiškumas } & „Beveik nesusiduria su korupcija“ & 463,72 & 110830,00 & 239 & 75112,000 & ,268 \\
\hline & „Dažnai susiduria su korupcija“ & 443,65 & 291923,00 & 658 & & \\
\hline & Iš viso & & & 897 & & \\
\hline \multirow{3}{*}{ Bejëgiškumas } & „Beveik nesusiduria su korupcija“ & 455,73 & 108920,50 & 239 & 77260,500 & ,645 \\
\hline & „Dažnai susiduria su korupcija“ & 447,24 & 294730,50 & 659 & & \\
\hline & Iš viso & & & 898 & & \\
\hline \multirow{3}{*}{ Neviltis } & „Beveik nesusiduria su korupcija“" & 457,29 & 109291,50 & 239 & 76411,500 &, 499 \\
\hline & „Dažnai susiduria su korupcija“ & 445,30 & 292564,50 & 657 & & \\
\hline & Iš viso & & & 896 & & \\
\hline \multirow{3}{*}{ Nenoras gyventi } & „Beveik nesusiduria su korupcija“" & 449,59 & 107451,00 & 239 & 78771,000 & ,972 \\
\hline & „Dažnai susiduria su korupcija“ & 450,15 & 297099,00 & 660 & & \\
\hline & Iš viso & & & 899 & & \\
\hline \multirow{3}{*}{ Baimè } & „Beveik nesusiduria su korupcija““ & 447,89 & 107046,00 & 239 & 78366,000 & ,994 \\
\hline & „Dažnai susiduria su korupcija“ & 448,04 & 293914,00 & 656 & & \\
\hline & Iš viso & & & 895 & & \\
\hline \multirow{3}{*}{ Liūdesys } & „Beveik nesusiduria su korupcija“ & 445,28 & 106202,00 & 239 & 77522,000 &, 741 \\
\hline & „Dažnai susiduria su korupcija“ & 450,69 & 296551,00 & 658 & & \\
\hline & Iš viso & & & 897 & & \\
\hline \multirow{3}{*}{ Kaltè } & „Beveik nesusiduria su korupcija“" & 445,28 & 106422,00 & 239 & 77742,000 &, 812 \\
\hline & „Dažnai susiduria su korupcija“ & 449,67 & 295434,00 & 657 & & \\
\hline & Iš viso & & & 896 & & \\
\hline \multirow{3}{*}{$\begin{array}{l}\text { Psichologinis } \\
\text { skausmas }\end{array}$} & „Beveik nesusiduria su korupcija“" & 452,16 & 108066,50 & 239 & 77636,500 &, 791 \\
\hline & „Dažnai susiduria su korupcija“ & 447,17 & 293789,50 & 657 & & \\
\hline & Iš viso & & & 896 & & \\
\hline \multirow{3}{*}{ Stresas } & „Beveik nesusiduria su korupcija“" & 460,60 & 109623,50 & 238 & &, 280 \\
\hline & „Dažnai susiduria su korupcija“ & 439,99 & 286871,50 & 652 & & \\
\hline & Iš viso & & & 890 & & \\
\hline \multirow{3}{*}{ Géda } & „Beveik nesusiduria su korupcija“" & 439,22 & 104094,00 & 237 & 75891,000 &, 682 \\
\hline & „Dažnai susiduria su korupcija“ & 446,42 & 290622,00 & 651 & & \\
\hline & Iš viso & & & 888 & & \\
\hline
\end{tabular}




\begin{tabular}{|l|l|l|l|l|l|l|}
\hline \multirow{4}{*}{$\boldsymbol{P y k t i s}$} & „Beveik nesusiduria su korupcija“ & 468,49 & 111969,00 & 239 & 74451,000 &, 188 \\
\cline { 2 - 8 } & „Dažnai susiduria su korupcija“ & 443,30 & 292581,00 & 660 & & \\
\cline { 2 - 8 } & Iš viso & & & 899 & & \\
\hline \multirow{3}{*}{ Nerimas } & „Beveik nesusiduria su korupcija“ & 471,04 & 113050,50 & 240 & 74029,500 &, 135 \\
\cline { 2 - 8 } & „Dažnai susiduria su korupcija“ & 442,34 & 291499,50 & 659 & & \\
\cline { 2 - 8 } & Iš viso & & & 899 & & \\
\hline
\end{tabular}

Kaip matyti iš 5 lentelëje pateiktų duomenų, Mann-Whitney testo rezultatai nebuvo statistiškai reikšmingi. Kitaip tariant, grupès nesiskyrẻ pagal emocinio patyrimo įverčius. Tai reiškia, kad tiriamųjų prisipažinimu apie tai, kokiuose sektoriuose jie susiduria su korupcija, galima pasitikèti - jų atsakymų neiškreipia neigiamas emocinis fonas, nes jis yra lygiai toks pat, kaip ir su korupcija nesusiduriančiu asmenų.

Toliau buvo siekiama išsiaiškinti, kaip susidūrimas su korupcija Lietuvoje gali paveikti asmens pasitenkinimą gyvenimu ir įvairiomis jo sritimis. Kèlème hipotezę, kad asmenys, kurie nesusiduria su korupcija, yra labiau patenkinti gyvenimu Lietuvoje, taip pat labiau patenkinti ịvairiomis savo gyvenimo sritimis. Ir priešngai, kẻlėme hipotezę, kad su korupcija dažnai susiduriantys asmenys bus labai nepatenkinti gyvenimu Lietuvoje ir išreikš nepasitenkinimą įvairiomis gyvenimo sritimis.

6 lentelè. Susidūrimo su korupcija ir pasitenkinimo gyvenimo sritimis palyginimas, Mann-Whitney testas

\begin{tabular}{|c|c|c|c|c|c|c|}
\hline Pasitenkinimas & & $\begin{array}{c}\text { Vidutiniai } \\
\text { rangai }\end{array}$ & $\begin{array}{c}\text { Rangụ } \\
\text { suma }\end{array}$ & $\mathbf{N}$ & $\begin{array}{c}\text { Mann- } \\
\text { Whitney }\end{array}$ & $\mathbf{p}$ \\
\hline \multirow{3}{*}{$\begin{array}{l}\text { Patenkintas } \\
\text { galimybe dirbti }\end{array}$} & „Beveik nesusiduria su korupcija“ & 233,29 & 39192,00 & 168 & 24996,00 &, 003 \\
\hline & „Dažnai susiduria su korupcija“ & 273,49 & 96268,00 & 352 & & \\
\hline & Iš viso & & & 520 & & \\
\hline \multirow{3}{*}{$\begin{array}{l}\text { Patenkintas } \\
\text { atlyginimu }\end{array}$} & „Beveik nesusiduria su korupcija“ & 240,30 & 40371,00 & 168 & 26175,00 &, 035 \\
\hline & „Dažnai susiduria su korupcija“ & 268,71 & 94050,00 & 350 & & \\
\hline & Iš viso & & & 518 & & \\
\hline \multirow{3}{*}{$\begin{array}{l}\text { Patenkintas } \\
\text { galimybe derinti } \\
\text { darbą ir poilsi }\end{array}$} & „Beveik nesusiduria su korupcija“ & 241,70 & 40605,50 & 168 & 26409,50 &, 048 \\
\hline & „Dažnai susiduria su korupcija“ & 268,04 & 93815,50 & 350 & & \\
\hline & Iš viso & & & 518 & & \\
\hline \multirow{3}{*}{$\begin{array}{l}\text { Patenkintas } \\
\text { finansine } \\
\text { situacija }\end{array}$} & „Beveik nesusiduria su korupcija“ & 411,95 & 98867,50 & 240 & 69947,50 &, 010 \\
\hline & „Dažnai susiduria su korupcija“ & 459,22 & 299410,5 & 652 & & \\
\hline & Iš viso & & & 892 & & \\
\hline \multirow{3}{*}{$\begin{array}{l}\text { Patenkintas } \\
\text { vartojimo } \\
\text { galimybèmis }\end{array}$} & „Beveik nesusiduria su korupcija“ & 414,79 & 99134,50 & 239 & 70454,50 &, 022 \\
\hline & „Dažnai susiduria su korupcija“ & 456,77 & 297360,5 & 651 & & \\
\hline & Iš viso & & & 890 & & \\
\hline
\end{tabular}




\begin{tabular}{|c|c|c|c|c|c|c|}
\hline \multirow{3}{*}{$\begin{array}{l}\text { Patenkintas } \\
\text { gyvenimo } \\
\text { sąlygomis }\end{array}$} & „Beveik nesusiduria su korupcija“ & 403,59 & 97669,50 & 242 & 68266,50 &, 000 \\
\hline & „Dažnai susiduria su korupcija“ & 469,72 & 310486,5 & 661 & & \\
\hline & Iš viso & & & 903 & & \\
\hline \multirow{3}{*}{$\begin{array}{l}\text { Patenkintas } \\
\text { gyvenamaja } \\
\text { aplinka }\end{array}$} & "Beveik nesusiduria su korupcija" & 408,69 & 98902,00 & 242 & 69499,00 &, 001 \\
\hline & "Dažnai susiduria su korupcija" & 467,86 & 309254,0 & 661 & & \\
\hline & Iš viso & & & 903 & & \\
\hline \multirow{3}{*}{$\begin{array}{l}\text { Patenkintas } \\
\text { kultūriniu } \\
\text { gyvenimu }\end{array}$} & „Beveik nesusiduria su korupcija“ & 418,15 & 99938,50 & 239 & 71258,50 &, 022 \\
\hline & „Dažnai susiduria su korupcija“ & 460,20 & 302814,5 & 658 & & \\
\hline & Iš viso & & & 897 & & \\
\hline \multirow{3}{*}{$\begin{array}{l}\text { Patenkintas } \\
\text { profesiniu } \\
\text { gyvenimu }\end{array}$} & „Beveik nesusiduria su korupcija“ & 417,67 & 99823,00 & 239 & 71143,00 &, 022 \\
\hline & „Dažnai susiduria su korupcija“ & 461,04 & 303828,0 & 659 & & \\
\hline & Iš viso & & & 898 & & \\
\hline \multirow{3}{*}{$\begin{array}{l}\text { Patenkintas } \\
\text { dvasiniu } \\
\text { gyvenimu }\end{array}$} & „Beveik nesusiduria su korupcija“ & 421,40 & 100714,0 & 239 & 72034,00 &, 035 \\
\hline & „Dažnai susiduria su korupcija“ & 460,36 & 303836,0 & 660 & & \\
\hline & Iš viso & & & 899 & & \\
\hline \multirow{3}{*}{$\begin{array}{l}\text { Patenkintas } \\
\text { psichologine } \\
\text { gerove }\end{array}$} & „Beveik nesusiduria su korupcija“ & 423,60 & 101240,5 & 239 & 72560,50 &, 058 \\
\hline & „Dažnai susiduria su korupcija“ & 458,89 & 302410,5 & 659 & & \\
\hline & Iš viso & & & 898 & & \\
\hline \multirow{3}{*}{$\begin{array}{l}\text { Patenkintas } \\
\text { materialine } \\
\text { padétimi }\end{array}$} & „Beveik nesusiduria su korupcija“ & 411,62 & 98376,00 & 239 & 69696,00 &, 005 \\
\hline & „Dažnai susiduria su korupcija“ & 463,90 & 306174,0 & 660 & & \\
\hline & Iš viso & & & 899 & & \\
\hline \multirow{3}{*}{$\begin{array}{l}\text { Patenkintas } \\
\text { medicinos } \\
\text { paslaugu } \\
\text { prieinamumu }\end{array}$} & „Beveik nesusiduria su korupcija“ & 309,26 & 56286,00 & 182 & 39633,00 &, 000 \\
\hline & „Dažnai susiduria su korupcija“ & 374,64 & 199684,0 & 533 & & \\
\hline & Iš viso & & & 715 & & \\
\hline \multirow{3}{*}{$\begin{array}{l}\text { Patenkintas } \\
\text { gyvenimu } \\
\text { Lietuvoje }\end{array}$} & „Beveik nesusiduria su korupcija“ & 386,07 & 93043,00 & 241 & 63882,00 &, 000 \\
\hline & „Dažnai susiduria su korupcija“ & 472,12 & 309710,0 & 656 & & \\
\hline & Iš viso & & & 897 & & \\
\hline
\end{tabular}

Kaip matyti iš 6 lentelëje pateiktų duomenų, Mann-Whitney testo rezultatai buvo statistiškai reikšmingi. Tačiau gauti duomenys yra paradoksalūs - jie ne tik nepatvirtino keltos hipotezès, bet pademonstravo visiškai priešingą, nei buvo tikètasi, rezultatą: dažniau susiduriantys su korupcija asmenys buvo statistiškai reikšmingai labiau patenkinti galimybe dirbti $(\mathrm{p}=, 003)$, labiau patenkinti atlyginimu $(\mathrm{p}=, 035)$, labiau patenkinti galimybe derinti darbą ir poilsị $(\mathrm{p}=, 048)$, labiau patenkinti finansine situacija $(\mathrm{p}=, 010)$, labiau patenkinti vartojimo galimybèmis $(\mathrm{p}=, 022)$, labiau patenkinti gyvenimo sąlygomis $(\mathrm{p}=, 000)$, labiau patenkinti gyvenamąja aplinka $(\mathrm{p}=, 001)$, labiau patenkinti kultūriniu gyvenimu $(\mathrm{p}=, 022)$, profesiniu gyvenimu $(\mathrm{p}=, 022)$, labiau patenkinti psichologine gerove $(\mathrm{p}=, 058)$, labiau patenkinti savo materialine padètimi $(\mathrm{p}=, 005)$, labiau patenkinti medicinos paslaugų prieinamumu $(p=, 000)$, labiau patenkinti gyvenimu Lietuvoje apskritai $(p=, 000)$. 
Ypatingai stebina tai, kad dažniau su korupcija susiduriantys asmenys buvo statistiškai reikšmingai labiau patenkinti savo dvasiniu gyvenimu $(p=, 035)$.

\section{Išvados}

Kaip rodo įvairiose šalyse atlikti tyrimai, korupcijos fenomenas paskatina netikèjimą pačiomis visuomeninès santvarkos taisyklèmis [12], menkina žmonių tikẻjimą valstybės funkcionavimo moraliniais pagrindais [15]. Nors šis fenomenas buvo tyrinètas ịvairiais skerspjūviais, taikant ịvairius teorinius modelius, Lietuvoje atliktas tyrimas papildè mokslinių tyrimų apie korupcijos reiškinị bazę.

Lietuvoje korupcijos fenomenas psichologiniu aspektu dar nebuvo išsamiai tyrinètas. Šiame straipsnyje pateikto tyrimo rezultatai supažindina su Lietuvos gyventojų imties požiūrio ị gyvenimą ir susidūrimo su korupcija specifika.

1. Tyrimas parodè, kad daugiau asmenų, dirbančių privačiame sektoriuje, lyginant su dirbančiais viešajame sektoriuje, teigè susiduriantys su korupcija gyvenamosios vietovès ịstaigose, savivaldybès ir valstybinèse įstaigose, švietimo, medicinos ir teisèsaugos institucijose, taip pat verslo sektoriuje. Šie duomenys gali būti aiškinami tuo, kad viešajame sektoriuje dirbantiems asmenims gali būti sunku ịsisąmoninti korupciją, nes tiketinai tai apsunkina psichikos gynybiniai mechanizmai, arba, priešingai, jie adekvačiau vertina realią situaciją, arba jiems rečiau tenka su tuo susidurti. İdomu, kad tyrimo rezultatai atskleide, jog Lietuvoje yra žymiai daugiau apskritai susiduriančių su korupcija nei nesusiduriančių su korupcija asmenų, o kai kuriuose segmentuose, pavyzdžiui, gyvenamos vietovès ịstaigose, susidūrimo su korupcija rodikliai yra ypatingai aukšti.

2. Aukščiausia susidūrimo su korupcija koreliacija stebima tarp valstybès ir savivaldybės įstaigų bei savivaldybių įstaigų ir ịstaigų gyvenamosios vietos aplinkoje.

3. Rezultatų analizè atskleidè statistiškai reikšmingus susidūrimo su korupcija dažnių pasiskirstymo skirtumus pajamų grupėse. Mažiausių pajamų asmenys teigé dažniausiai susiduriantys su korupcija teisèsaugos, verslo, valstybės įstaigų sektoriuose bei vertinant korupciją visuose sektoriuose apskritai, lyginant su kitomis pajamų grupèmis.

4. Siekdami palyginti respondentų, kurie teigè „dažnai susiduriantys" arba „beveik nesusiduriantys“ su korupcija, emocingumą, atlikome analizę, kuri parodè, kad grupès nesiskyre pagal emocinio patyrimo ịverčius, ir tiriamųjų prisipažinimu apie tai, kokiuose sektoriuose jie susiduria su korupcija, galima pasitikèti - jų atsakymų neiškreipė neigiamas emocinis fonas.

5. Buvo keliama hipotezè, kad asmenys, kurie nesusiduria su korupcija, yra labiau patenkinti gyvenimu Lietuvoje, taip pat labiau patenkinti ịvairiomis savo gyvenimo sritimis, ir priešingai, - su korupcija dažnai susiduriantys asmenys yra nepatenkinti gyvenimu Lietuvoje ir nepatenkinti ịvairiomis gyvenimo sritimis. Gauti duomenys yra paradoksalūs - jie ne tik nepatvirtino keltos hipotezės, bet pademonstravo visiškai priešingą, nei buvo tikètasi, efektą: dažniau susiduriantys su 
korupcija asmenys buvo statistiškai reikšmingai labiau patenkinti galimybe dirbti, atlyginimu, galimybe derinti darbą ir poilsị, finansine situacija, vartojimo galimybėmis, gyvenimo sąlygomis, gyvenamąja aplinka, kultūriniu gyvenimu, profesiniu gyvenimu, psichologine gerove, savo materialine padètimi, medicinos paslaugu prieinamumu, gyvenimu Lietuvoje apskritai. Ypatingai nustebino tai, kad dažniau su korupcija susiduriantys asmenys buvo statistiškai reikšmingai labiau patenkinti savo dvasiniu gyvenimu. Taigi, gautus rezultatus pavadinome susidūrimo su korupcija ir pasitenkinimo gyvenimu paradoksu, nes jie prieštarauja kitų mokslininkų atliktiems darbams $[16 ; 17]$.

6. Galbūt susidūrimo su korupcija ir pasitenkinimo gyvenimu paradoksą galima būtų aiškinti remiantis kai kurių autorių modeliais (Fein \& Weibler, 2014, Rabl 2011, Maravic, 2007, Aguilera \& Vadera, 2008; Shadnam \& Lawrence, 2011), vis dèlto gauti duomenys yra nuviliantys. Jie rodo, kad nors žmonės supranta, kas yra korupcijos fenomenas, nors pripažịsta susiduriantys su korupcija įvairiuose sektoriuose, tačiau tai nemenkina jų pasitenkinimo gyvenimu Lietuvoje, priešingai gyvenimu Lietuvoje, savo materialine ir finansine padètimi bei galimybėmis yra labiau patenkinti tie, kurie dažniau susiduria su korupcija. Šis paradoksas turètų būti toliau tyrinejjamas, nes jis gali reikšti, kad Lietuvoje daugelis žmonių ne tik nebetiki valstybès funkcionavimo moraliniais pagrindais, bet ir patys tokių pagrindų nebeturi.

\section{Literatūra}

1. Aguilera, R. V., \& Vadera, A. K. (2008). The dark side of authority: Antecedents, mechanisms, and outcomes of organizational corruption. Journal of Business Ethics, 77(4), 431-449. doi: 10.1007/s10551-007-9358-8.

2. Beugré, C. D. (2010). Resistance to socialization into organizational corruption: A model of deontic justice. Journal of Business Psychology, 25(3), 533-541. doi: 10.1007/s10869-010-9176-3.

3. Chang, J. J., \& Lai, C. C. (2002). Is the efficiency wage efficient? The social norm and organizational corruption. Scandinavian Journal of Economics, 104(1), 27-47. doi: 10.1111/1467-9442.00270.

4. Commons, M. L. (2008). Introduction to the model of hierarchical complexity and it relationship to postformal action. World Futures, 64(5-7), 305-320. doi: $10.1080 / 02604020802301105$.

5. Fein, E., \& Weibler, J. (2014). Cognitive basis for corruption and attitudes towards corruption viewed from a structuralist adult developmental meta-perspective. Behavioral Development Bulletin, 19(3).

6. Kohlberg, L. (1984). The Psychology of Moral Development: The Nature and Validity of Moral Stages (Essays on Moral Development, Volume 2). Harper \& Row.

7. Lange, D. (2009). A multidimensional conceptualization of organizational corruption control. Academy of Management Review, 33(3), 710-729. doi: 10.5465/ 
AMR.2008.32465742.

8. Maravic, P. V. (2007). Public management reform and corruption: Conceptualizing the unintended consequences. Administration and Public Management Review, 8, 126-148.

9. Rabl, T. (2011). The impact of situational influences on corruption in organizations. Journal of Business Ethics, 100(1), 85-101. doi: 10.1007/ s10551-011-0768-2.

10. Shadnam, M., \& Lawrence, T. B. (2011). Understanding widespread misconduct in organizations: An institutional theory of moral collapse. Business Ethics Quarterly, 21(3), 379-407.

11. Treviño, L. K., Weaver, G. R., \& Reynolds, S. R. (2006). Behavioral ethics in organizations: a review. Journal of Management, 2006, 32(6), 951- 990. doi: $10.1177 / 0149206306294258$

12. Bai, B. Y., Liu, X. X., \& Kou, Y. (2014). Belief in a just world lowers perceived intention of corruption: The mediating role of perceived punishment. PLOS ONE, 9(5), 1-7. doi:10.1371/journal.pone.0097075.

13. Cohen, T. R., Wolf, S. T., Panter, a T., \& Insko, C. a. (2011). Introducing the GASP scale: a new measure of guilt and shame proneness. Journal of Personality and Social Psychology, 100(5), 947-966. doi:10.1037/a0022641.

14. Fein, E. (2014). Cognitive basis for corruption and attitudes towards corruption in organizations viewed from a structuralist adult developmental meta-perspective. Behavioral Development Bulletin, 19, 78-94.

15. Rothstein, B. (2013). Corruption and Social Trust: Why the Fish Rots from the Head Down. Social Research, 80(4), 1009-1033.

16. Wang, L., \& Murnighan, J. K. (2013). Money, Emotions, and Ethics Across Individuals and Countries. Journal of Business Ethics, (February 2013), 1-14. doi:10.1007/s10551013-1914-9.

17. Zaloznaya, M. (2014). The Social Psychology of Corruption: Why It Does Not Exist and Why It Should. Sociology Compass, 2, 187-202.

Aistė Diržytė, Aleksandras Patapas

\section{Paradox of Lithuanian Residents' Corruption Experience and Satisfaction with Life}

\section{Summary}

Much of the debate over corruption has focused on the role of various psychological, economic, political factors. As it is shown in the overview of the current tendencies in research, there is a variety of models explaining the phenomenon of corruption. The presented study aimed at evaluating psychological profiles (emotions, satisfaction with various life domains) of people, stating that they have often experienced corruption. This paper presents some results of the survey, which was conducted in 2014 in Lithuania $(n=1002)$. The analysis of Lithuanian data has demonstrated that the higher are rates of corruption experience, the higher is satisfaction with life in Lithuania as well as satisfaction with the financial situation, consuming possibilities, etc. The authors come to the conclusion that these results could be 
named "paradox of Lithuanian residents' corruption experience and satisfaction with life". The authors indicate that additional research is needed.

Aistė Diržytė, Mykolo Romerio universiteto Psichologijos instituto docentè, Psichologinès gerovès tyrimų laboratorijos vadovè, psichologijos mokslų daktarè.

E. paštas aidir@mruni.eu

Aleksandras Patapas, Mykolo Romerio universiteto Viešojo administravimo instituto docentas, filosofijos mokslų daktaras.

E. paštas patapas@mruni.eu

Aisté Diržytė, Doctor of Psychology, Associated Professor at the Institute of Psychology, Mykolas Romeris University, Head of Psychological Wellbeing Research Laboratory.

E-mail: aidir@mruni.eu

Aleksandras Patapas, Doctor of Philosophy, Associated Professor at the Institute of Public Administration, Mykolas Romeris University.

E-mail:patapas@mruni.eu

Straipsnis įteiktas redakcijai 2015 m. gegužès mèn.; recenzuotas; parengtas spaudai 2015 m. birželio mèn. 